\title{
Design Methodology for Grout Curtains Under Dams Founded on Rock
}

\author{
Suihan Zhang (D) Fredrik Johansson (1) • Håkan Stille
}

Received: 13 April 2021 / Accepted: 9 November 2021 / Published online: 18 November 2021

(C) The Author(s) 2021

\begin{abstract}
Grout curtains are commonly constructed under dams to reduce the seepage through the rock foundation. In the design of grout curtains, empirical methods have mainly been used since the introduction of dam foundation grouting. Although empirical methods have been used with success in several projects, they have their limitations, such as poor control of the grout spread, only an indirect consideration of the threat of internal erosion of fracture infillings in the grouted zones, and the risk of hydraulic jacking. This paper presents a theory-based design methodology for grout curtains under dams founded on rock. In the design methodology, the grout curtain is designed as a structural component of the dam. The risk of erosion of fracture infilling material is explicitly accounted for along with the reduction of the hydraulic conductivity of the rock mass, and an optimization of the total uplift force. By applying the proposed design methodology, engineers can create a design better adapted to the prevailing geological and hydrogeological conditions in the rock mass, resulting in more durable grout curtains. The proposed
\end{abstract}

S. Zhang $(\bowtie) \cdot$ F. Johansson $\cdot$ H. Stille

Division of Soil and Rock Mechanics, Department of

Civil and Architectural Engineering, KTH Royal Institute of Technology, Brinellvägen 23, 10044 Stockholm,

Sweden

e-mail: suihan@kth.se

F. Johansson

e-mail: fredrik.johansson@byv.kth.se methodology also enables cost and time estimates to be calculated for the grout curtain's construction. Applying the principles of the observational method during the grouting execution also allows the design to be modified via predefined measures if the initial design is found to be unsuitable.

Keywords Grout curtain - Dam - Rock mass · Internal erosion $\cdot$ Stop criteria
List of Symbols
Latin letters
$b \quad$ Physical aperture of the fractures within a borehole section, $\mu \mathrm{m}$
$b_{\mathrm{b}} \quad$ Boundary fracture aperture, defined as the aperture for which a fully sealed curtain is achieved in the design, $\mu \mathrm{m}$
$b_{\text {crit }} \quad$ Critical aperture, the smallest aperture in which the grout can freely penetrate, $\mu \mathrm{m}$
$b_{\mathrm{m}} \quad$ Estimated maximum physical aperture within a section, $\mu \mathrm{m}$
$b_{\mathrm{mh}} \quad$ Hydraulic aperture of the largest fracture, $\mu \mathrm{m}$
$E \quad$ Elastic modulus of the rock mass, GPa
$g \quad$ Gravity of earth, $\mathrm{m} / \mathrm{s}^{2}$
$H_{\text {down }}$ Hydraulic head downstream of the grout curtain, $m$
$H_{\mathrm{w}} \quad$ Hydraulic head of the reservoir upstream of the grout curtain, $m$
$h \quad$ Depth of the fracture, $m$
I Actual grout spread 
$I_{\mathrm{D}} \quad$ Relative grout spread

$I_{\max } \quad$ Maximum radial grout spread, $\mathrm{m}$

$I_{\mathrm{n}} \quad$ Normalized grout spread

$i_{\text {crit }} \quad$ Critical hydraulic gradient not to be exceeded in order to prevent the infilling materials from being eroded, $\mathrm{m} / \mathrm{m}$

$i_{\mathrm{g}} \quad$ Hydraulic gradient within the grouted zone, $\mathrm{m} / \mathrm{m}$

$K \quad$ Hydraulic conductivity, $\mathrm{m} / \mathrm{s}$

$K_{\text {acc }} \quad$ Acceptable hydraulic conductivity in the grouted zone, $\mathrm{m} / \mathrm{s}$

$K_{\mathrm{g}} \quad$ Estimated residual hydraulic conductivity in the grouted zone, $\mathrm{m} / \mathrm{s}$

$k_{1} \quad$ Ratio between mean and maximum $T_{\mathrm{S}}$ of all hydraulic tests in the project with the prerequisite that they contain the same geological domain

$k_{2} \quad$ Ratio between section transmissivity $T_{\mathrm{s}}$ and the transmissivity of the largest fracture $T_{\mathrm{fm}}$

$k_{3} \quad$ Ratio between the maximum physical aperture and $b_{\mathrm{mh}}$

$k_{4} \quad$ Ratio between the critical aperture $b_{\text {crit }}$ and the boundary fracture aperture $b_{\mathrm{b}}$

$k_{\mathrm{n}} \quad=\frac{3}{4} \frac{E}{\left(1-v^{2}\right)} \frac{\delta_{a c c}}{\rho g h^{2}} \frac{P_{g}}{P_{e}}$

$k_{2}^{\prime} \quad$ Parameter indicating the non-contacted part of the fracture

$L \quad$ Section length between packers in the borehole, $\mathrm{m}$

$P_{\mathrm{e}} \quad$ Excess pressure from the pressurized grout acting on the fracture walls, MPa

$P_{\mathrm{g}} \quad$ Grouting pressure, $\mathrm{MPa}$

$P_{\mathrm{i}} \quad$ Critical pressure, the pre-stress on the fracture, $\mathrm{MPa}$

$P_{\mathrm{n}} \quad$ Normalized grouting pressure

$P_{\mathrm{w}} \quad$ Water pressure at the fracture, $\mathrm{MPa}$

$\Delta P_{\mathrm{g}} \quad$ Effective grouting pressure, $\mathrm{MPa}$

$Q \quad$ Grout flow rate, $\mathrm{L} / \mathrm{s}$

$T \quad$ Thickness of the grout curtain, $m$

$T_{\mathrm{fm}} \quad$ Transmissivity of the largest fracture, $\mathrm{m}^{2} / \mathrm{s}$

$T_{\mathrm{s}} \quad$ Section transmissivity, $\mathrm{m}^{2} / \mathrm{s}$

$t \quad$ Grouting time, $\mathrm{s}$

$t_{\mathrm{D}} \quad$ Relative grouting time

$t_{0} \quad$ Characteristic grouting time, $\mathrm{s}$

$U$ Total uplift force, $\mathrm{kN} / \mathrm{m}$

$U_{\mathrm{i}} \quad$ Uplift force for different possible designs of the grout curtain, $\mathrm{kN} / \mathrm{m}$

$U_{\min } \quad$ Minimum uplift force, $\mathrm{kN} / \mathrm{m}$
$V_{\text {tot }} \quad$ Total grout volume injected into a section of a rock mass, $\mathrm{L}$

W Base width of the dam, $m$

\section{Greek Letters}

$\delta_{\text {acc }}$ Maximum allowed elastic deformation close to the borehole, $\mathrm{mm}$

$\theta_{2 \mathrm{D}}=\frac{t_{D}}{2\left(3+t_{D}+0.23 \ln \left(t_{D}\right)\right)}$

$\mu \quad$ Dynamic viscosity of water, Pa.s

$\mu_{\mathrm{g}} \quad$ Viscosity of grout, $\mathrm{Pa} \cdot \mathrm{s}$

$v \quad$ Poisson's ratio of the rock mass

$\rho \quad$ Density of the rock mass, $\mathrm{kg} / \mathrm{m}^{3}$

$\rho_{\mathrm{w}} \quad$ Density of water, $\mathrm{kg} / \mathrm{m}^{3}$

$\tau_{0} \quad$ Yield value of the grout, $\mathrm{Pa}$

\section{Introduction}

Grout curtains are a common method used to reduce the hydraulic conductivity of the rock mass under different types of dams, and thus control the water seepage in it (USBR 1976; Houlsby 1990; ICOLD 1993; CDA 2007; Weaver and Bruce 2007; FERC 2016). Particularly for concrete dams, the grout curtain, together with the drainage system, reduces the uplift pressure, which, if too high, could jeopardize the sliding stability of the dam (Casagrande 1961; Ruggeri 2004; Chai and Cui 2012). For embankment dams, excessive seepage caused by insufficient grouting of the rock foundation could lead to internal erosion of the impervious dam core through the foundation, resulting in catastrophic consequences, as was the case with the Teton dam failure in 1976 (Seed and Duncan 1987).

The design of the grout curtains and the design of the grouting work have long been based on empirical practices. Classic grouting textbooks such as those by Houlsby (1990) and Weaver and Bruce (2007) have introduced the empirical design principles of grout curtains. However, even though the empirical design principles have been successfully employed in many projects, limitations still exist. The application of the empirical design principles requires that the practicing engineer have extensive experience; otherwise, an inadequate or over-conservative design may be the result (Wilson and Dreese 2003). In addition, when using the empirical design principles, the risk of internal erosion of fracture infilling materials is only considered indirectly by adjusting the 
acceptable Lugeon value with respect to the rock mass quality, despite the fact that internal erosion of fracture infilling materials could potentially cause or accelerate deterioration of the grout curtain (Weaver and Bruce 2007; Spross et al. 2016; Ewert and Hungsberg 2018). Furthermore, the empirical "refusal" stop criterion which defines a minimum flow rate when grouting should cease (Weaver and Bruce 2007; El Tani and Lopez-Molina 2019), can lead to longer grouting time and higher costs, but not equivalently better quality. Thus, the efficiency of this criterion is doubtful. According to the empirical design principles, the grouting pressure is also chosen according to existing "rules of thumb", which can cause hydraulic jacking if not properly selected (Weaver and Bruce 2007; Rafi and Stille 2015a).

To deal with the limitations incorporated into the empirical design principles, a more theoretically based design principle would be preferable. Grouting is, however, by its very nature, a complex process involving interactions between the rock mass, the grout, and the groundwater. Many important aspects shall be considered before, during and after the process. In recent decades, extensive research has been aimed at theoretically describing various aspects of rock grouting, including hydrogeology in the rock mass (Zimmerman and Bodvarsson 1996; Gustafson 2012; Hernqvist et al. 2014; Zou et al. 2015), grout mix properties (Håkansson 1993; Eriksson and Stille 2003; Eklund and Stille 2008; Draganović and Stille 2011, 2014), grout penetration length (Gustafson and Stille 2005; Stille et al. 2009; El Tani 2012; El Tani and Stille 2017; Funehag and Thörn 2018; Zou et al. 2018, 2020), grouting pressure (Lombardi and Deere 1993), rock deformation (hydraulic jacking) during grouting (Brantberger et al 2000; Gothäll and Stille 2009; Rafi and Stille 2015b), and the erosion of fresh grout (Axelsson 2009). Stille (2015) summarized the new theories on rock grouting, and Stille et al. (2012) specified their applications on dam foundation grouting. These summaries from Stille presented several aspects of the grouting work, but without combining all these aspects into an overall design framework for grout curtains. From the grout curtain perspective, Wilson and Dreese (2003) discussed the possibility of a quantitatively engineered grout curtain as "an engineered structure". The focus was mainly on the geometry of the curtain in relation to its effect on reducing the seepage. The durability of the grout curtain, which, among other things, could be threatened by internal erosion of fracture infilling materials, was not discussed.

Attempts have also been made to design the grouting work in a more analytical manner. The GIN method introduced by Lombardi and Deere (1993) proposed a grouting method based on the specific energy expended in the grouting process. Even though the GIN method has been implemented with success (Lombardi and Deere 1993), doubts and arguments still exist regarding the applicability of the method (Bonin et al. 2012; Rafi and Stille 2015a). Carter et al. (2012) proposed a grouting procedure named Aperture Controlled Grouting (ACG), suggesting that the analytically estimated grout take volume be used as the stop criteria. The procedure's implementation in the field was discussed by Bonin et al. (2012). Although ACG is seen as an advancement for the grouting work, the grout spread in the fractures, which is essential for the closure of the grout curtain, remains unclear.

Despite the different attempts to design the grouting work and the grout curtain, a systematic theory-based design methodology involving both the grout curtain (as a structural component) and the grouting work has not yet been developed. The absence of a theory-based design methodology creates room for further development. A systematic theory-based design methodology can bridge the gap between theories and the actual design, thus improving the quality of the grout curtain, increasing the efficiency of the grouting work, and enabling the implementation of the principles of the observational method to reduce the risk of, for example, internal erosion and hydraulic jacking.

In this paper, the main objective is to present a thorough discussion on the theories of rock grouting in the context of grout curtains under dams. As a result of the discussion, we propose a novel design methodology for grout curtains under dams founded on rock. The methodology is mainly based on existing theories on rock grouting organized under a complete design framework. Compared to the existing design methodologies of grout curtains, the proposed methodology considers the grout curtain as a structural component of the dam and the grout curtain is designed with analytical calculations. The novelty specifically lies in how to address the risk of erosion of fracture infilling materials in the grouting design, which has not explicitly been considered in previous design 
methods. A brief outline defining the requirements of the grout curtain in the methodology was introduced by Zhang and Johansson (2021). The remainder of the paper is organized as follows: The principles of the design methodology for grout curtains under dams founded on rock are first introduced. Theories for each aspect of the grouting are then described according to the corresponding step in the framework of the design methodology. Following the principles of the design framework, a design example using the methodology is presented, followed by concluding remarks.

\section{Design Methodology}

\subsection{Overview of the Design Framework}

The new suggested design methodology for grout curtains is summarized and presented in a flow chart in Fig. 1. It consists of three phases: preliminary design, grouting execution, and dam safety management.

The first phase, preliminary design of the grout curtain, aims to determine the grout curtain geometry as well as the corresponding grouting parameters for obtaining the determined geometry. As shown in Fig. 1, the preliminary design phase involves four steps: (i) geological and hydrogeological investigations, (ii) definition of requirements on the grout curtain, (iii) design of the grout curtain, and (iv) design of the grouting work.

The preliminary design starts with Geological and hydrogeological investigations, which provide the designers with information about the rock mass characteristics at the site. The second step in the first phase is to define requirements on the grout curtain. Based on the results of the site investigations performed in the previous step, the requirements on the grout curtain are defined and specified according to the acceptable hydraulic conductivity (tightness), the critical gradient with respect to internal erosion of the fracture infilling materials, and an optimization of the total uplift force. Design of the grout curtain is the third step, where the geometries of the grout curtain, including its position, depth and thickness, are to be designed based on the requirements defined in the previous steps. The fourth and last step in the preliminary design phase is the design of the grouting work. Design of the grouting work focuses on preparing a grouting plan in order to obtain the geometry of the grout curtain designed in the third step. In this final step, grouting parameters and contingency plans for unexpected behavior during grouting should also be defined. This last step includes the instructions for the grouting execution phase based on the principles of the observational method. Both the second and the third step must be done with respect to the design of the dam, as different types of dams and their characteristics can present different requirements and limitations on the grout curtain. The last step, which is the design of the grouting work, is usually carried out by different designers from the first three steps, as indicated by the division line in Fig. 1.

The second phase after the preliminary design is the grouting execution. The principles of the observational method should be followed in this phase, and the quality of the grouting operation needs to be constantly controlled.

In the third phase, during the operation of the dam, the pore pressure and leakage should be monitored continuously, and measures should be implemented if necessary to maintain dam safety. If monitoring indicates any deterioration of the grout curtain, remedial grouting of the grout curtain or other types of measures may be needed.

\subsection{Preliminary Design}

\subsubsection{Geological and Hydrogeological Investigations}

Geological and hydrogeological investigations provide important information about the rock mass characteristics which are essential for the design of grout curtains, including fracture patterns, possible infilling materials in the fractures, hydraulic conductivity of the rock mass, fracture transmissivity, etc. The methods for conducting various geological and hydrogeological investigations can be found in textbooks or standards such as Houlsby (1990), Weaver and Bruce (2007), ISO (2012a, 2012b, 2012c), and Palmström and Stille (2014).

To start the design process, hydraulic fracture apertures need to be derived based on the results from Lugeon tests. As concluded by Stille et al. (2012), and according to several studies (Gustafson and Stille 1996; Funehag and Fransson 2006), the fracture aperture is a reasonable predictor for penetration length of the grout, and is therefore a key parameter in the design process. 


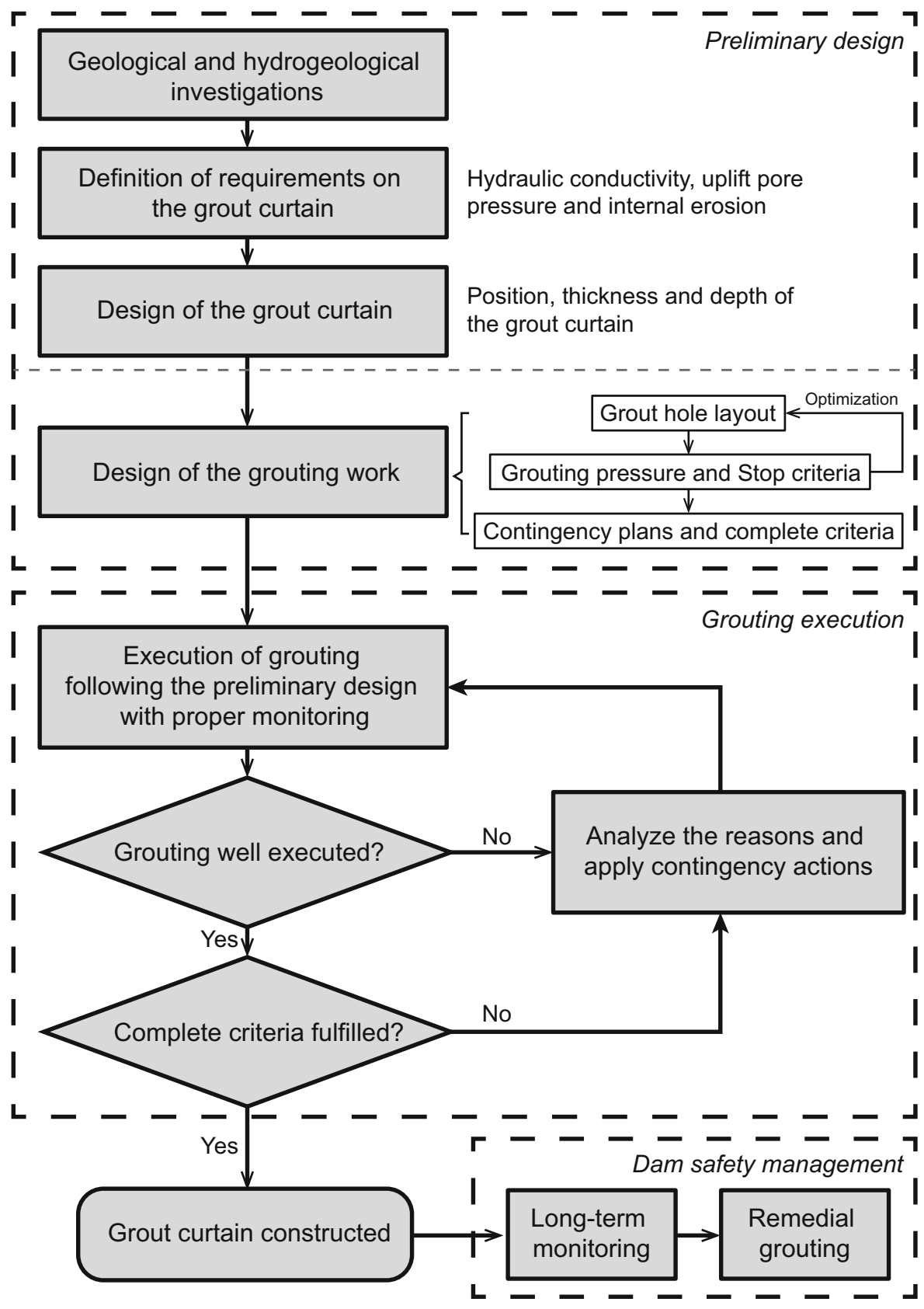

Fig. 1 Flowchart illustrating the principles of the design methodology for grout curtains

The hydraulic aperture of the largest fracture of a tested section can be estimated from Lugeon tests, given that most of the total section transmissivity from such a test is contributed by the largest fracture in the section (Hernqvist et al. 2014). However, it can be difficult to estimate the extent of this contribution exactly. Thus, this contribution needs to be assumed based on the observation of fracture patterns from the geological investigations. To facilitate this, Stille (2015) introduced the coefficient $k_{2}$, which is defined as the ratio between section transmissivity $T_{\mathrm{s}}$ and the transmissivity of the largest fracture $T_{\mathrm{fm}}$. as

$T_{f m}=\frac{T_{s}}{k_{2}}$. 
According to Stille (2015), $k_{2}$ normally varies between 1.1 and 2.0. The hydraulic aperture of the largest fracture $b_{\mathrm{mh}}$ can thus be calculated based on the cubic law, as

$b_{m h}=\sqrt[3]{\frac{T_{f m} \cdot 12 \mu}{\rho_{w} g}}$,

where $\mu$ is the dynamic viscosity of water $\left(1.3 \bullet 10^{-3} \mathrm{~Pa} \bullet\right.$ s at $\left.10^{\circ} \mathrm{C}\right)$ and $\rho_{\mathrm{w}}$ is the density of water $\left(1,000 \mathrm{~kg} / \mathrm{m}^{3}\right)$.

\subsubsection{Requirements on the Grout Curtain}

The purpose of the grout curtain under a dam is to decrease the seepage in the rock mass by reducing the hydraulic conductivity of the rock mass, and to reduce the uplift pore pressure. The grout curtain must also be constructed with high quality and designed with acceptable durability. One important aspect of the durability is to prevent internal erosion of the fracture infilling materials within the grouted zone if such material is present. These three purposes (i.e. reduce hydraulic conductivity of the rock mass, prevent internal erosion, and reduce uplift pore pressure) constitute the basis for defining the requirements on the grout curtain.

The acceptable hydraulic conductivity in the grouted zone $K_{\text {acc }}$ is normally chosen according to the classes of grouting suggested by Houlsby (1990). 3 Lugeons need to be reached if piping of the foundation material needs to be prevented. If not, the standard varies from 5 to 15 Lugeons for embankment dams, and 3 to 7 Lugeons for concrete dams. However, as a widely accepted yet old standard, Houlsby's classes of grouting may need further revision in the future. The requirement is presented in Eq. (3) and implies that the estimated residual hydraulic conductivity in the grouted zone $K_{\mathrm{g}}$ should be lower than or equal to $K_{\text {acc }}$ :

$K_{\mathrm{g}} \leq K_{\text {acc }}$.

Infilling materials such as clay, sand, and other mineral sediments or rock fragments may exist in rock fractures (Barton 1973; Winberg et al. 2003). In the unsealed parts of the fractures in the grouted zone, some of the infilling materials can be eroded by flowing water if the velocity is sufficiently high (Axelsson 2009; Ewert and Hungsberg 2018). Normal cement-based grouts can penetrate materials whose hydraulic conductivity is higher than approximately $5 \bullet 10^{-4} \mathrm{~m} / \mathrm{s}$ (Littlejohn 1982). This implies that coarse sand, rock fragments, etc. can be seen as sealed, since they can be penetrated by the cement-based grouts. On the other hand, fine cohesive sediments such as clay may not be erodible by the flow in the grouted zone due to the strong cohesion between particles (Nilsen and Palmström 2001). Hjulström (1935) suggested that erosion of a clayey cohesive bed requires average water velocities higher than $0.2 \mathrm{~m} / \mathrm{s}$, even though this study was performed on a riverbed and not within a rock fracture, where the hydraulic conditions are different. Zhang and Johansson (2021) therefore suggested that the risk of erosion in the grouted zones is greatest for small non-cohesive particles such as, for example, fine sand or silt. In clay, this risk has to be studied on a case-to-case basis depending on the cohesive bonds between particles.

A high hydraulic gradient implies high velocity in the fractures, and monitoring the hydraulic gradient is normally easier than measuring the flow velocity in the grouted zone. Therefore, the requirement for preventing internal erosion can be presented as a criterion for the hydraulic gradient $i_{\mathrm{g}}$ within the grouted zone as

$i_{\mathrm{g}}<i_{\text {crit }}$,

where $i_{\text {crit }}$ is the critical hydraulic gradient not to be exceeded in order to prevent the infilling materials from being eroded. The $i_{\text {crit }}$, however, is still a topic to be discussed. Very limited research has been conducted focusing on the erosion of infilling materials in rock fractures. Therefore, thresholds from other studies (for example, the incipient motion of sediments or contact erosion in embankment dams) could be used as a rough approximation for the erosion of fracture infilling materials. However, this should be performed with careful analysis and evaluation since the hydraulic conditions in a rock fracture is different compared to these studies.

The grout curtain reduces the seepage through the rock mass and thus contributes to the reduction of the uplift force (Ruggeri 2004). This reduction is usually not accounted for in the assumptions for the pore pressure used in the stability calculation of the dam body (USBR 1976; FERC 2016; Swedenergy 2017), but could rather be seen as an added safety margin. To maximize this safety margin, the grout curtain should be designed to minimize the total uplift force $U$, such as in 


$$
U=\min \left(U_{i}\right),
$$

where $U_{\mathrm{i}}$ is the uplift force for different possible designs of the grout curtain.

Among the three requirements, the acceptable residual hydraulic conductivity requirement should always be fulfilled together with the requirement pertaining to the erosion of infilling materials, if they are present in the fractures. However, the requirement to minimize the total uplift force is only optional for optimization and does not necessarily need to be fulfilled for all possible design alternatives as long as the two other criteria are fulfilled and the uplift pressure assumed in the stability calculations for the dam are not exceeded. In addition to these three requirements, the geochemical aspect of the type of grout material used and its interaction with groundwater also affects the durability of the grout curtain and can under certain conditions be an important issue to consider. It is, however, beyond the focus of this paper, and therefore will not be further discussed.

\subsubsection{Design of the Grout Curtain}

Design of the grout curtain implies determining the position, the thickness and the depth of the grout curtain. A section of a typical concrete dam illustrating

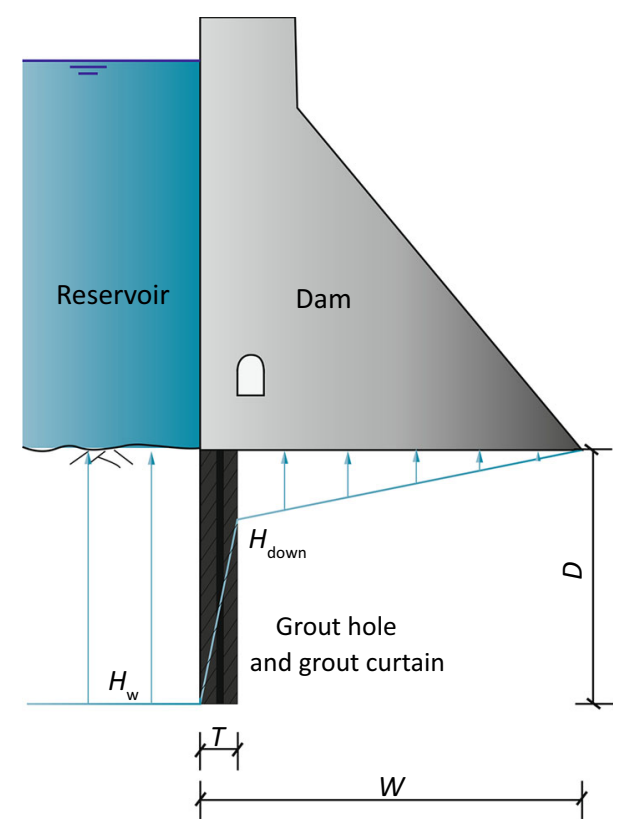

Fig. 2 Schematic profile of a concrete dam with grout curtain the geometrical parameters of the grout curtain incorporated into the design is presented in Fig. 2.

The most suitable position of the grout curtain varies depending on the type of dam. For concrete dams, the grout curtain is mostly positioned at the heel of the dam, while for embankment dams the grout curtain is normally located under the core of the dam at a position near the centerline of the core, see for example Houlsby (1990).

A multi-factor method is employed when designing the thickness of the grout curtain based on the work by Zhang and Johansson (2021) considering the three requirements in Sect. 2.2.2. The $K_{\mathrm{g}}$ in the first requirement in Eq. (3) can be predicted using the equation proposed by Stille (2015), and defined as:

$K_{g}=\frac{k_{1} k_{2}}{k_{3}^{3} k_{4}^{3}} \frac{1}{L} \frac{\rho_{w} g}{12 \mu} b_{c r i t}^{3}$,

where $L$ is the tested section length between the packers in the borehole, $k_{l}$ is the ratio between the mean and the maximum $T_{\mathrm{s}}$ of all hydraulic tests in the project with the prerequisite that they contain the same geological domain. If not, different values for each geological domain shall be derived. According to Stille (2015), $k_{1}$ usually varies between 0.2 and 0.6 . A small $k_{1}$ indicates a tight rock mass, and a higher value indicates a more permeable rock mass. $k_{2}$ is the ratio between $T_{\mathrm{s}}$ and $T_{\mathrm{fm}}$, and usually varies between 1.1 and 2.0 according to Stille (2015). $k_{3}$ is the ratio between the maximum physical aperture and $b_{\mathrm{mh}}$, varying between 1.5 and 2.0 (Zimmerman and Bodvarsson 1996; Tsuji et al. 2012). $k_{4}$ is the ratio between the critical aperture $b_{\text {crit }}$, defined as the smallest aperture in which the grout can freely penetrate, and the boundary fracture aperture $b_{\mathrm{b}}$, defined as the aperture for which a fully sealed curtain is achieved in the design.

Fractures finer than $b_{\mathrm{b}}$ can be simplified as unsealed in the design phase as a conservative approach, since it is both time-consuming and costly to seal fine fractures (i.e. with apertures approximately equal to $\left.b_{\text {crit }}\right)$. Therefore, $k_{4}$ can be a value less than 1 in the design if the $K_{\text {acc }}$ allows it. The value of $b_{\text {crit }}$ depends on the grain size of the cement-based grout. According to Eklund and Stille (2008), the aperture shall be at least three times the grain size to penetrate freely for coarse cements. For micro-cement, however, the ratio 
can be considerably higher than 3 due to its tendency to flocculate (Stille 2015).

In the design of the grouting work described in Sect. 2.2.4, $b_{\mathrm{b}}$ is used when determining the grouting pressure, the stop criteria, as well as the grout hole layout. It should be noted that when estimating the injected volume of the grout, the maximum physical aperture is used instead.

Based on the assumptions that the rock mass could be simplified as a continuous media, and that the uplift pressure under the dam is distributed according to a bilinear distribution as illustrated in Fig. 2, Zhang and Johansson (2021) combined Eq. (6) and Darcy's law, resulting in an expression connecting the thickness of the grout curtain $T$ to $U$, as:

$U=\left[\frac{H_{\text {down }}(W-T)}{2}+\frac{\left.\left(H_{\text {down }}+H_{w}\right) T\right)}{2}\right] \bullet \rho_{w} g$,

$H_{\text {down }}=\frac{b_{c r i t}^{3}(W-T)}{b_{c r i t}^{3}(W-T)+k_{3}^{3} k_{4}^{3} b_{m h}^{3} T} H_{w}$,

where $W$ is the base width of the dam, $H_{\text {down }}$ is the hydraulic head downstream of the grout curtain and $H_{\mathrm{w}}$ is the hydraulic head of the reservoir upstream of the grout curtain.

Based on Eq. (7) and (8), $U$ can be calculated for different values of $T$. The value of $T$ that results in $U_{\min }$ constitutes the optimal thickness of the curtain, provided that $K_{\mathrm{g}} \leq K_{\mathrm{acc}}$.

However, a small thickness of the grout curtain can induce a steep hydraulic gradient within the grouted zone. Therefore, the thickness of the grout curtain must fulfill the requirement in Eq. (4) so that $i_{\text {crit }}$ is not exceeded. By inserting $H_{\text {down }}$ from Eq. (8) into the definition of $i_{\mathrm{g}}$, Zhang and Johansson (2021) derived the following expression for calculating $i_{\mathrm{g}}$

$i_{g}=\frac{H_{w}-H_{\text {down }}}{T}=\frac{k_{3}^{3} k_{4}^{3} b_{m h}^{3}}{b_{c r i t}^{3}(W-T)+k_{3}^{3} k_{4}^{3} b_{m h}^{3} T} H_{w}$.

As shown in Eq. (5), $i_{\mathrm{g}}$ should be smaller than $i_{\text {crit }}$ to prevent erosion of any ungrouted infilling materials in the grouted zone.

The depth of the grout curtain needs to be determined according to the hydrogeological investigations and the $K_{\text {acc }}$. If the investigations indicate that the natural hydraulic conductivity of the rock mass is lower than $K_{\text {acc }}$ below a certain depth, this depth can be taken as the depth for the grout curtain. If the hydraulic conductivity of the rock mass is constant or increases with depth, the depth of the grout curtain can then be determined based on common practices, for example, the recommendations by Houlsby (1990), stating that the depth of the curtain should be equal to the reservoir water head.

\subsubsection{Design of the Grouting Work}

The grouting work is designed to achieve the grout curtain geometry in the preliminary design based on the requirements in Sect. 2.2.2 and the theories in Sect. 2.2.3. A grout hole can be divided into vertical sections. Instead of grouting the entire grout hole in one grouting run, sectional grouting divided by packers is recommended in the design methodology proposed in this paper. The grouting work should therefore be designed for each vertical section in a grout hole. As a simplification, the grout holes which share the same geological domain can share the same design. The procedure for the design of the grouting work for one geological domain is as follows:

1. Establish an initial layout of the grout holes. Set up the number of rows of the grout holes, the spacing between each row, and the spacing between the adjacent holes within each row. Given the thickness of the grout curtain determined in Sect. 2.2.3, requirements for the minimum grout spread can be determined.

2. Set an initial grouting pressure for each vertical section of the grout hole, and calculate the grout spread curve versus time for each section. From the minimum grout spread, determine the stop criteria (the grouting time) of grouting for each vertical section based on the grout hole layout and the required grout curtain thickness. Evaluate the risk for hydraulic jacking. If the initial design assumptions do not fulfill the jacking requirements, this step should be repeated using lower grouting pressure until the jacking requirements are fulfilled.

3. Optimize the grout hole layout through an iterative procedure of Step 1 and 2 until a satisfactory design of the grouting work is achieved.

4. Prepare a monitoring plan and necessary contingency actions for the grouting work. Define the 
acceptance criteria for unfavorable behaviors and the corresponding alternative designs or other contingency actions. Establish the complete criteria for the grouting work.

\subsubsection{Prediction of grout spread and flow under constant grouting pressure}

With the grout being modelled as a Bingham fluid, the maximum radial grout spread $I_{\max }$ can be calculated as (Gustafson and Stille 1996):

$I_{\max }=\frac{\Delta P_{g}}{2 \tau_{0}} b_{b}$,

where $\tau_{0}$ is the yield value of the grout, $\Delta P_{\mathrm{g}}$ is the effective grouting pressure, which is the difference between the grouting pressure $P_{\mathrm{g}}$ and the water pressure at the fracture $P_{\mathrm{w}}$

$\Delta P_{g}=P_{g}-P_{w}$.

To define the stop criteria, the relationship between grout spread and grouting time is needed. Relative grouting time $t_{\mathrm{D}}$ and relative grout spread $I_{\mathrm{D}}$ were therefore introduced in the analytical solutions by Gustafson and Stille (2005). They defined $t_{\mathrm{D}}$ as

$t_{D}=\frac{t}{t_{0}}$,

where $t$ is the grouting time and $t_{0}$ is the characteristic grouting time. $t_{0}$ is defined as

$t_{0}=\frac{6 \Delta P_{g} \mu_{g}}{\tau_{0}^{2}}$,

where $\mu_{\mathrm{g}}$ is the viscosity of grout. The $I_{\mathrm{D}}$ were defined as

$I_{D}=\frac{I}{I_{\max }}$,

where $I$ is the actual grout spread.

The grout spread in a fracture is assumed to be 2D. A solution for $I_{\mathrm{D}}$ in relation to $t_{\mathrm{D}}$ for $2 \mathrm{D}$ radial spread was presented by Stille et al. (2009) as

$I_{D}=\sqrt{\theta_{2 D}^{2}+4 \theta_{2 D}}-\theta_{2 D}$

where $\theta_{2 \mathrm{D}}$ is

$\theta_{2 D}=\frac{t_{D}}{2\left(3+t_{D}+0.23 \ln \left(t_{D}\right)\right)}$.
The relationship between $I_{\mathrm{D}}$ and $t_{\mathrm{D}}$ is unique whereas the relationship between $I$ and $t$ varies with different grouting parameters. There is still an ongoing discussion on the solution of the $2 \mathrm{D}$ spread of a Bingham fluid (El Tani 2012; El Tani and Stille 2017; Zou et al. 2020), although the different solutions give similar results on the grout spread (Stille 2015; Zou et al. 2020).

Stille (2015) suggested that the total grout volume injected into a section of a rock mass $V_{\text {tot }}$ can be calculated according to the geometrical volume of a disc with a radius of $I$ as

$V_{t o t}=\pi I_{D}^{2}\left(\frac{\Delta P_{g}}{2 \tau_{0}}\right)^{2} \sum b^{3}$,

where $b$ is the physical aperture of the fractures within a borehole section. The flow rate $Q$ can thus be calculated as the first order derivatives of the injected volume over time

$Q=\frac{d V_{t o t}}{d t}=2 \pi I_{D} \frac{d I_{D}}{d t_{D}} \frac{1}{t_{0}}\left(\frac{\Delta P_{g}}{2 \tau_{0}}\right)^{2} \sum b^{3}$.

If reliable Lugeon tests have been performed in the grout holes, the calculation of the injected grout volume can be used as an estimation for predicting the grout usage.

\subsubsection{Layout of the grout holes and stop criteria}

The initial grout hole layout, including the spacing between the holes and the number of rows, can, as a first attempt, be based on empirical practice. The defined thickness of the grout curtain and the initial layout provide information on the required grout spread for each grout hole section according to the following principle.

The thickness does not equal double the grout spread. Instead, the overlapping of the grout spread from two adjacent holes determines the thickness of the grout curtain (Zhang and Johansson 2021), as shown in Fig. 3. In the figure, the thickness of the grout curtain is defined as the maximum length of the overlapping area in the direction perpendicular to the grout curtain. Therefore, the minimum grout spread can be estimated by geometrical calculations.

For each grout hole section, stop criteria are determined according to the curves showing grout spread length (calculated using $b_{\mathrm{b}}$ ) vs grouting time. 


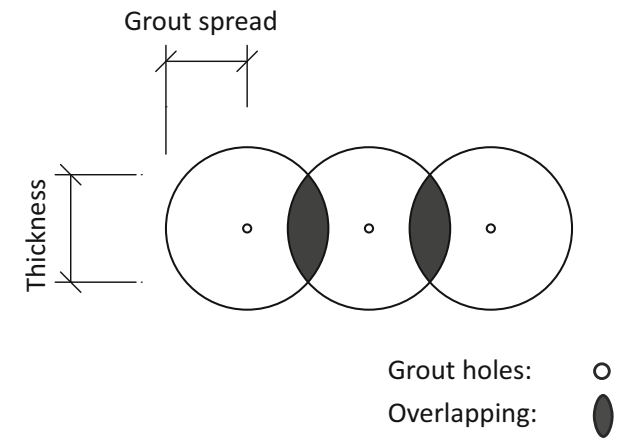

Fig. 3 Determination of the thickness of the grout curtain based on overlapping of the grout spread

The grouting time at which the minimum grout spread is reached becomes the stop criterion for the grouting in the corresponding grout hole section.

The determination of the grout hole layout and the stop criteria is an iterative process; if the minimum grout spread estimated in the initial layout takes too long to grout, which implies poor efficiency, a new layout should be designed with smaller spacing, and thus a shorter grout spread.

\subsubsection{Grouting pressure with respect to hydraulic jacking}

The constant grouting pressure after the initial pressure build-up, together with the calculated grout spread, are used to control the risk against jacking. If the pressure and the grout spread do not fulfill the jacking requirement, decreasing the grouting pressure or limiting the grouting time are the options to choose from. The stop criteria should then be adjusted accordingly.

To determine if there is a risk of jacking, the following calculation procedure was recommended by Stille et al. (2012).

It starts with normalizing the grouting pressure to a normalized pressure $P_{\mathrm{n}}$

$P_{n}=\frac{\Delta P_{g} \bullet k_{2}^{\prime}}{3 \rho g h}$,

where $\Delta P_{\mathrm{g}}$ is the effective grouting pressure, $k_{2}^{\prime}$ is a parameter indicating the non-contacted part of the fracture, usually set as $1, \rho$ is the density of the rock mass, and $h$ is the depth of the fracture. The normalization is also performed on $I$, resulting in a normalized grout spread $I_{\mathrm{n}}$
$I_{n}=\frac{I}{h}$.

As the grouting pressure can be seen as constant along the vertical section, a longer grout spread will result in a greater uplift force acting on the fracture. Therefore, the $I$ in Eq. (20) is the grout spread in the fracture with maximum aperture. The risk of elastic jacking can be expressed as a relation between $P_{\mathrm{n}}$ and $I_{\mathrm{n}}$

$P_{n}+\frac{P_{w}}{3 \rho g h} \leq \frac{k_{n}}{3 I_{n}}+\frac{1}{3}$.

$k_{\mathrm{n}}$ is calculated as

$k_{n}=\frac{3}{4} \frac{E}{\left(1-v^{2}\right)} \frac{\delta_{a c c}}{\rho g h^{2}} \frac{P_{g}}{P_{e}}$,

where $E$ is the elastic modulus of the rock mass, $v$ is Poisson's ratio, and $\delta_{\text {acc }}$ is the maximum allowed elastic deformation close to the borehole. $P_{\mathrm{e}}$ is the excess pressure from the pressurized grout acting on the fracture walls, calculated from the grouting pressure $P_{\mathrm{g}}$ and the pre-stress on the fracture, named critical pressure $P_{\mathrm{i}}$

$P_{e}=P_{g}-P_{i}$.

An example of an elastic jacking limit is plotted in Fig. 4.

Apart from checking that the elastic deformations are within acceptable levels, uncontrolled irreversible ultimate jacking should also be prevented. A limiting state for ultimate jacking was proposed by Brantberger et al. (2000) and later modified by Stille et al. (2012) as

$P_{n}+\frac{P_{w}}{\rho g h} \leq 1+\frac{1}{I_{n}}+\frac{1}{3 I_{n}^{2}}$.

During the design phase, $P_{\mathrm{n}}$ should be plotted as a function of $I_{\mathrm{n}}$. This curve should not cross either of the two limits in Fig. 4 to ensure that no unfavorable jacking occurs. As shown in Fig. 4(b), the limit for ultimate jacking will be lower than the limit for elastic jacking for shallow fractures, which means that the ultimate jacking occur before the elastic jacking. It should also be noted that the model for elastic jacking assumes that the rock mass above the fracture deforms elastically. For grouting in shallow fractures, the elasticity may not be able to develop. Therefore, the use of elastic jacking for shallow fractures without any modification may be questioned. 
Fig. 4 Limit states for ultimate jacking and elastic jacking expressed by the normalized effective grouting pressure as a function of normalized grout spread. a: limit states for deep fractures; $\mathbf{b}$ : limit states for shallow fractures (after Stille et al. 2012)

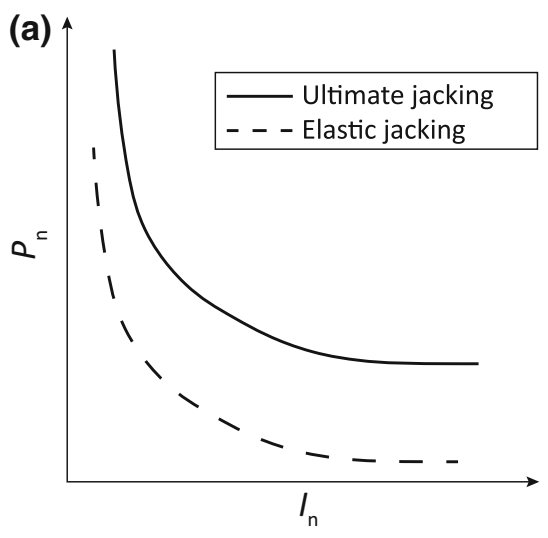

Deep fractures

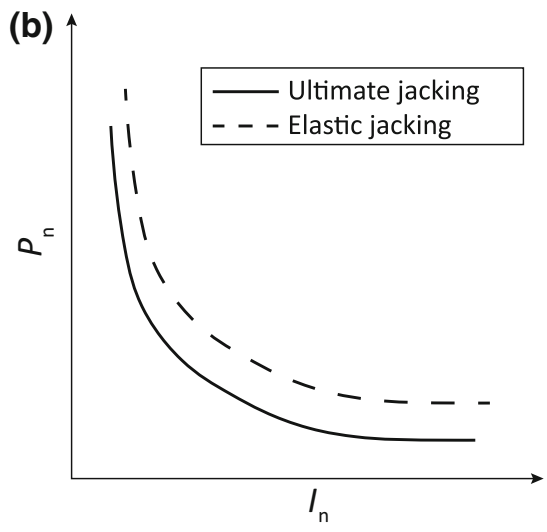

Shallow fractures

\subsubsection{Contingency plans and complete criterion}

The principles of the observational method provide an ideal framework to deal with uncertainties related to the grouting execution. Prior to the beginning of grouting, possible unfavorable scenarios must be considered, including hydraulic jacking, unexpected rock mass properties, sudden changes in flow, etc. Proper contingency plans should be prepared for all unfavorable scenarios before the grouting starts. A complete contingency plan includes a monitoring plan, acceptance criteria for each unfavorable scenario and corresponding contingency actions. Clear instructions on the acceptance criteria which will trigger the contingency actions are essential, see for example Spross et al. (2016).

A complete criterion is also required as a signal that the grouting is completed. One of the options for such a criterion is the residual hydraulic conductivity. The criterion is fulfilled when the tested residual hydraulic conductivity in the grouted zone is lower than the acceptable hydraulic conductivity. If the criterion is fulfilled for all the grouted zones, the grouting work can be determined as completed. If not, supplementary grouting, including the addition of grout holes, is required.

\subsection{Grouting Execution}

The grouting execution should be performed according to the preliminary design. During the execution, the grouting personnel should be able to perform the grouting in a high-quality manner and with good control over the whole process. The principles of the observational method demand good judgement during the grouting process and quick decisions on whether to trigger the contingency actions. Proper and strict supervision should be provided. Although this phase contains more on-site work rather than "design", the review and refinement of the preliminary design should be performed whenever required according to the on-site observations.

\subsection{Dam Safety Management}

The dam foundation should be constantly monitored over the long-term. Indirect measuring, through pore pressure measurements for example, are required to indirectly monitor the functionality of the grout curtain. If no significant difference in pore pressure can be measured between the grout curtain's upstream and downstream sides, the grout curtain may have deteriorated. The stability of the dam should also be assessed regularly, and the critical uplift force should not be exceeded. If the total uplift force approaches the critical value, remedial grouting or other measures need to be implemented.

\subsection{Limitations}

The proposed design methodology consists of rock grouting theories which are based upon specific prerequisites, which implies that the methodology has certain limitations. The methodology can only be used for the design of grout curtains under new dams where the hydraulic gradient in the rock mass is low, otherwise erosion of the fresh grout can occur. In addition, the methodology is limited to fractured rock 
masses where the grout spread occurs radially in the discrete fractures and should not be applied for permeation grouting of homogenous material such as sand. Furthermore, the methodology is only applicable for grout with Bingham properties, such as cementitious grout, and needs to be performed under temperature conditions which prevent freezing and enable hardening of the grout.

\section{Design Example: Grout Curtain Under a Fictitious Concrete Gravity Dam}

To illustrate the preliminary design process, a design example for the grout curtain under a fictitious concrete gravity dam is presented. For simplicity, alternative designs and other contingency actions are omitted in this example. It is furthermore assumed that the whole rock foundation belongs to the same geological domain.

The geometry of the dam is based on a typical concrete dam in Sweden, as shown in Fig. 5. The dam to be built has a height of $22 \mathrm{~m}$ and the base width is $15 \mathrm{~m}$. The water head in the filled reservoir is assumed to be $20 \mathrm{~m}$ and the groundwater level before construction of the dam is assumed to be at the surface of the rock foundation. The dam is assumed to be founded on a fractured rock mass of hard crystalline rock consisting of granite. The rock mass rating (RMR) is roughly equivalent to 70 , which indicates a good rock mass quality. The rock mass properties related to the design are presented in Table 1. Lugeon tests are assumed to have been performed in a sectional manner with the testing length of each

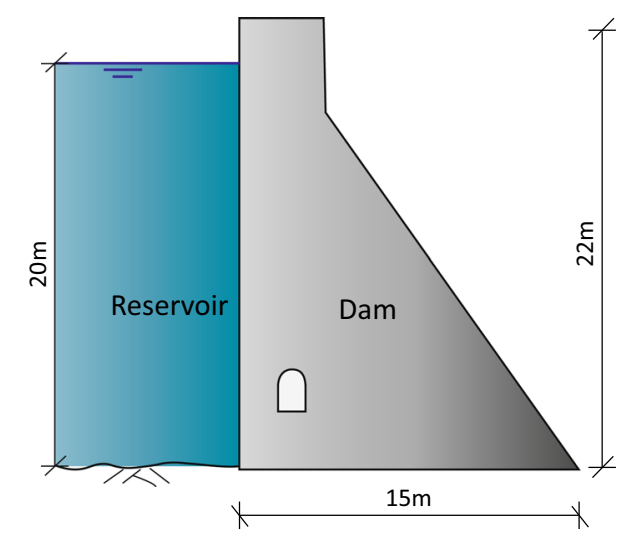

Fig. 5 The fictitious dam for the design example
Table 1 Assumed rock mass properties from geological investigations

\begin{tabular}{llll}
\hline$E(\mathrm{GPa})$ & $v$ & $\rho\left(\mathrm{kg} / \mathrm{m}^{3}\right)$ & Infilling materials \\
\hline 40 & 0.2 & 2.6 & Silt and fine sand \\
\hline
\end{tabular}

section being $4 \mathrm{~m}$. The assumed results from the Lugeon tests are listed in Table 2 . The grout is initially selected as a relatively fine-grained cement-based grout, Injektering 30 (INJ30, Draganović and Stille 2011), with a w/c ratio of 1.0. Its rheological properties have been tested in the laboratory by Stille et al. (2012), and the results are presented in Table 3.

The design example has been created in accordance with the flow chart in Fig. 1. The results of the hydrogeological investigations are first interpreted. Then, the requirements on the grout curtain are defined, followed by the design of the grout curtain. The grouting work is thereafter designed, which includes defining the stop criteria and the layout of the grout holes.

\subsection{Interpretation of the Investigation Results}

Based on the results from the Lugeon tests, the hydrogeological properties of the rock mass can be estimated as shown in Table 4 . In Table $4, K$ represents the hydraulic conductivity while $b_{\mathrm{m}}$ is the estimated maximum physical aperture within a section. The assumption that the largest fracture contributes to $80 \%$ of the total transmissivity in a section is made for this example according to Sect. 2.2.1. $k_{2}$ is chosen to 1.25 to estimate the maximum hydraulic aperture using Eqs. (1) and (2).

\subsection{Requirements on the Grout Curtain}

As discussed in Sect. 2.2.2, three requirements need to be fulfilled: (i) an acceptable residual hydraulic conductivity must be obtained; (ii) the internal erosion of any infilling materials shall be prevented; and (iii) the total uplift force should be minimized. The design should fulfill requirements (i) and (ii) simultaneously, while requirement (iii) is acceptable as long as (i) and (ii) have been fulfilled and the total uplift force does not exceed the estimate made in the design of the concrete dam. 
Table 2 Assumed results from the Lugeon tests

\begin{tabular}{|c|c|c|c|c|c|c|}
\hline \multirow[t]{2}{*}{ Hole $n r$} & \multicolumn{2}{|c|}{ Measurement depth in rock } & \multirow[t]{2}{*}{ Test length (m) } & \multirow[t]{2}{*}{ Test pressure (MPa) } & \multirow[t]{2}{*}{ Time (min) } & \multirow[t]{2}{*}{ Water loss (liters) } \\
\hline & from $(\mathrm{m})$ & to $(\mathrm{m})$ & & & & \\
\hline \multirow[t]{7}{*}{1} & 0 & 4 & 4 & 0.3 & 2 & 40 \\
\hline & 4 & 8 & 4 & 0.3 & 2 & 30 \\
\hline & 8 & 12 & 4 & 0.3 & 2 & 35 \\
\hline & 12 & 16 & 4 & 0.3 & 2 & 15 \\
\hline & 16 & 20 & 4 & 0.3 & 2 & 8 \\
\hline & 20 & 24 & 4 & 0.3 & 2 & 2 \\
\hline & 24 & 28 & 4 & 0.3 & 2 & 1 \\
\hline
\end{tabular}

Table 3 Rheological properties of the grout INJ30 w:c $=1.0$

\begin{tabular}{lll}
\hline$\mu_{\mathrm{g}}(\mathrm{Pa} \bullet \mathrm{s})$ & $\tau_{O}(\mathrm{~Pa})$ & $b_{\text {crit }}(\mu \mathrm{m})$ \\
\hline 0.02 & 6 & 90 \\
\hline
\end{tabular}

The acceptable $K_{\mathrm{g}}$ in this example is set to $1 \mathrm{Lu}$ based on the guidelines established by Houlsby (1990) (the highest standard). Due to the absence of a clear threshold with respect to the erosion of infilling materials in rock fractures, the critical velocity for contact erosion of embankment dams has been used as a rough approximation. ICOLD (2017) summarized the studies regarding the contact erosion of embankment dams. Based on this summary, a velocity of $0.01 \mathrm{~m} / \mathrm{s}$, which is lower than the threshold velocities from all the studies presented in the summary, is used as a conservative critical value to initiate the erosion of fine sand. The $i_{\text {crit }}$ is therefore calculated at $10 \mathrm{~m} / \mathrm{m}$ under the assumption that the flow in the sand-filled fractures follows Darcy's law with a conductivity of fine sand equal to $1 \bullet 10^{-3} \mathrm{~m} / \mathrm{s}$. Further research is needed on the erosion of fracture infilling materials to better select $i_{\text {crit }}$.

\subsection{Design of the Grout Curtain}

With regard to the requirement for residual conductivity, the depth of the grout curtain can be determined by using the values in Table 4 . As seen by the values in the table, below a depth of $20 \mathrm{~m}$ the rock mass has a natural conductivity lower than the required value, meaning that the depth of the grout curtain does not have to be more than $20 \mathrm{~m}$.

To proceed with the design, Eq. (6) is used, where $k_{1}$ is calculated to 0.47 based on the results in Table 4 . In this example, $k_{2}$ is assumed to be 1.25 and $k_{3}$ assumed to be 2.0. $k_{4}$ is calculated to 0.45 based on a $b_{\mathrm{b}}$ of $200 \mu \mathrm{m}$ and a $b_{\text {crit }}$ of $90 \mu \mathrm{m}$. Based on these values, $K_{\mathrm{g}}$ is calculated to $9.37 \bullet 10^{-8} \mathrm{~m} / \mathrm{s}$ or $0.6 \mathrm{Lu}$ in the

Table 4 Estimated hydrogeological properties of the rock mass

\begin{tabular}{|c|c|c|c|c|c|c|}
\hline \multicolumn{2}{|c|}{ Depth in rock $(\mathrm{m})$} & \multirow{2}{*}{$\begin{array}{l}\text { Lugeon value (liters/m.min.MPa) } \\
17\end{array}$} & \multirow{2}{*}{$\begin{array}{l}K\left(\mathrm{~m}^{3} / \mathrm{s} \bullet \mathrm{m} \bullet \mathrm{m}\right) \\
2.78 \mathrm{E}-06\end{array}$} & \multirow{2}{*}{$\begin{array}{l}T_{\mathrm{s}}\left(\mathrm{m}^{3} / \mathrm{s} \bullet \mathrm{m}\right) \\
1.11 \mathrm{E}-05\end{array}$} & \multirow{2}{*}{$\begin{array}{l}b_{\mathrm{mh}}(\mu \mathrm{m}) \\
240\end{array}$} & \multirow{2}{*}{$\begin{array}{l}b_{\mathrm{m}}(\mu \mathrm{m}) \\
480\end{array}$} \\
\hline 0 & 4 & & & & & \\
\hline 4 & 8 & 13 & $2.08 \mathrm{E}-06$ & 8.33E-06 & 218 & 437 \\
\hline 8 & 12 & 15 & 2.43E-06 & $9.72 \mathrm{E}-06$ & 230 & 460 \\
\hline 12 & 16 & 6 & 1.04E-06 & 4.17E-06 & 173 & 346 \\
\hline 16 & 20 & 3 & $5.56 \mathrm{E}-07$ & 2.22E-06 & 140 & 281 \\
\hline 20 & 24 & 1 & 1.39E-07 & $5.56 \mathrm{E}-07$ & 89 & 177 \\
\hline 24 & 28 & 0 & 6.94E-08 & $2.78 \mathrm{E}-07$ & 70 & 140 \\
\hline
\end{tabular}


0-4 m vertical section, which fulfills the requirement. The deeper sections whose fracture apertures are smaller are expected to fulfill the requirement without further verification.

Due to the uncertainties that these assumptions imply, a sensitivity analysis of the coefficients $k_{2}, k_{3}$ and $k_{4}$ is performed. The results presented in Fig. 6 show that $K_{\mathrm{g}}$ is sensitive to changes in the values of $k_{2}$, $k_{3}$ and $k_{4} . k_{3}$ and $k_{4}$ are particularly sensitive to changes in their $k$ values. If these coefficients are arbitrarily chosen within their possible ranges, the deviation of $K_{\mathrm{g}}$ is quite significant. If strict requirements for $K_{\mathrm{g}}$ exist, it is therefore important to perform thorough geological and hydrogeological investigations in order to derive credible values for these coefficients.

Determining the thickness of the grout curtain is based on a comparison of $i_{\text {crit }}$ against $i_{\mathrm{g}}$ and an optimization of $U$ under different values of $T$ as shown in Fig. 7. In the figure, the curve for $U$ shows that a thickness of approximately $3 \mathrm{~m}$ will give the minimum $U$. The curve for $i_{\mathrm{g}}$ becomes lower than $i_{\text {crit }}$ at a thickness of $1 \mathrm{~m}$, which implies that a thickness larger than $1 \mathrm{~m}$ will fulfill the requirement for preventing internal erosion of the sand infilling. Based on these results, a thickness of $3 \mathrm{~m}$ is chosen.

\subsection{Initial Grout Hole Layout}

Following the design procedure in Sect. 2.2.4, an initial grout hole layout first needs to be established as

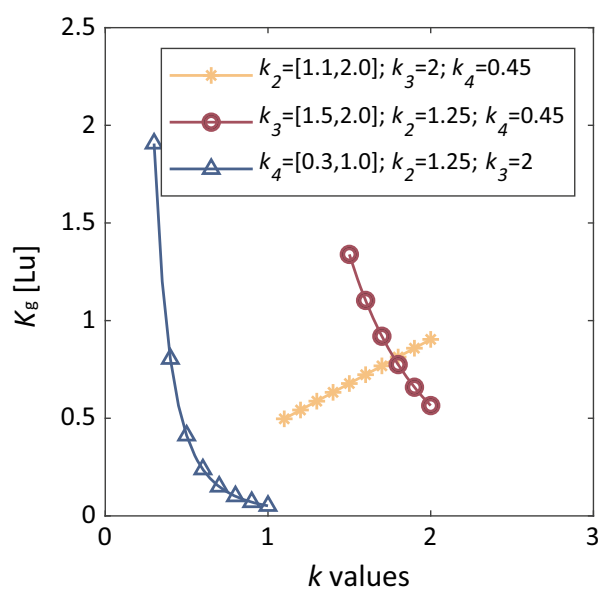

Fig. 6 Sensitivity analyses of the parameters $k_{2}, k_{3}$ and $k_{4}$ with respect to $K_{\mathrm{g}}$

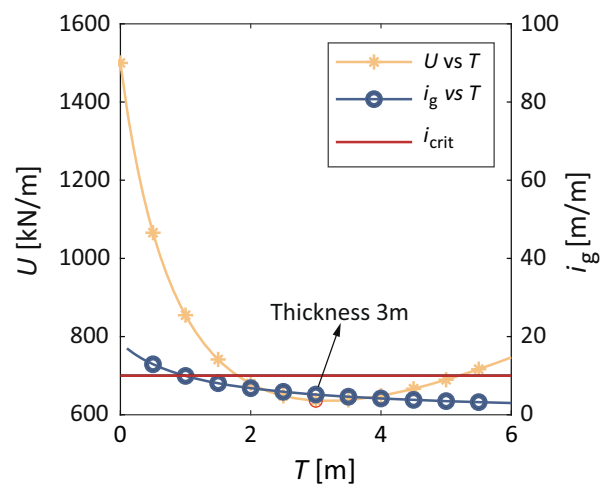

Fig. 7 Determining the thickness of the grout curtain

the starting point of the design of the grouting work. In this design example, to obtain the 3-m thickness of the curtain, an initial grout hole layout as illustrated in Fig. 8 is first chosen. This layout consists of two rows of vertical holes. The deep holes are to be drilled to full depth $(20 \mathrm{~m})$ with $8-\mathrm{m}$ spacing in row 1 . Due to a potential jacking problem in the shallow rock mass, the grouting pressure in the shallow Sects. (0-4 m section in the design example) of the deep holes is reduced. With this reduced pressure, the 8-m spacing is too large for the grout spread to overlap in the 0-4 m section. Additional shallow holes were therefore chosen to be drilled in between the deep holes in row 1 and throughout row 2 , to a depth of $4 \mathrm{~m}$ with a spacing of $2 \mathrm{~m}$ to deal with the jacking problem and to obtain the 3-m thickness. The two rows are $1.5 \mathrm{~m}$ apart and row 2 consists of shallow holes only.

With the initial grout hole layout, the minimum required grout spread to obtain the 3-m thickness at different sections of the grout holes is then estimated. The grout is assumed to spread radially from the grout hole. For all the grout holes in the $0-4 \mathrm{~m}$ section, the grout should spread at least $1.3 \mathrm{~m}$ from each hole to obtain the desired thickness. For the deeper sections, the minimum required grout spread needs to be $4.3 \mathrm{~m}$ from each hole to reach the desired thickness. The required spread of the grout is obtained by choosing suitable stop criteria with respect to the grouting time, and the initial layout is then subjected to a jacking check according to the steps presented in Sect. 3.5.

\subsection{Stop Criteria and Grouting Pressure}

Suitable stop criteria for grouting in different sections are required to obtain the minimum grout spread from 
Fig. 8 The initial grout hole layout with the required minimum grout spread
0-4 m:
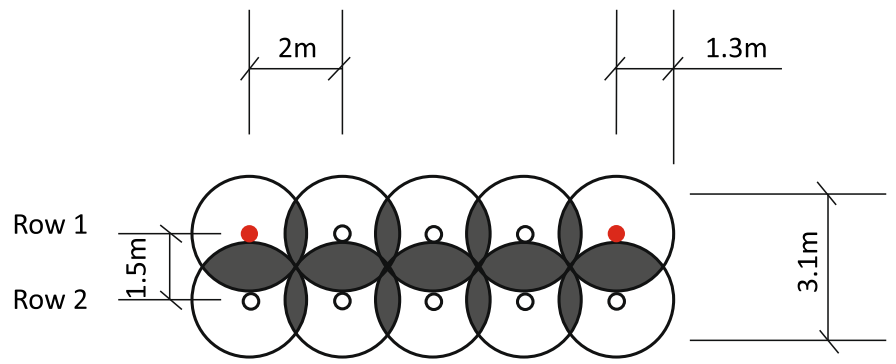

4-20 m:

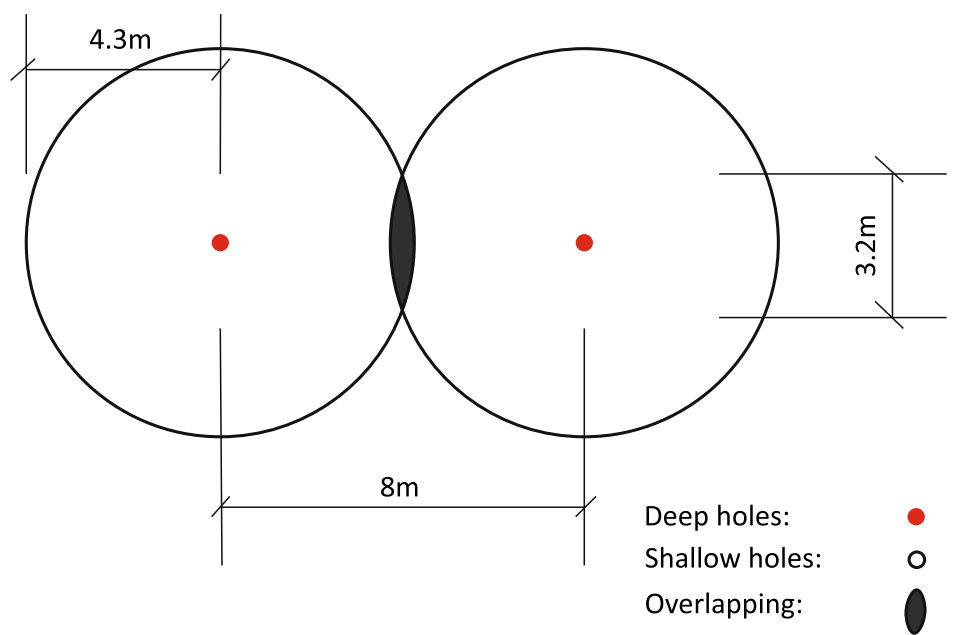

the initial grout hole layout, where Eqs. (10) to (16) are used to obtain the stop criteria. In this example, the design is only for the $0-4 \mathrm{~m}$ section and $4-8 \mathrm{~m}$ section respectively. The grouting pressure and grouting time for the 4-8 $\mathrm{m}$ section can be applied to deeper sections due to the fact that deeper sections are less prone to hydraulic jacking.

$\Delta P_{\mathrm{g}}$ is initially chosen to be $0.2 \mathrm{MPa}$ for the $0-4 \mathrm{~m}$ section, and $0.5 \mathrm{MPa}$ for the $4-8 \mathrm{~m}$ section. $I_{\max }$ and its corresponding $t_{0}$ under the chosen pressures are calculated and presented in Table 5. I against $t$ is then calculated and plotted in Fig. 9.

Based on the calculated spread, the stop criterion for the $0-4 \mathrm{~m}$ section is chosen to be $200 \mathrm{~s}(\sim 4 \mathrm{~min})$ for a corresponding grout spread of $1.3 \mathrm{~m}$. For the 4-8 m section, the stop criterion is chosen to be $1070 \mathrm{~s}$

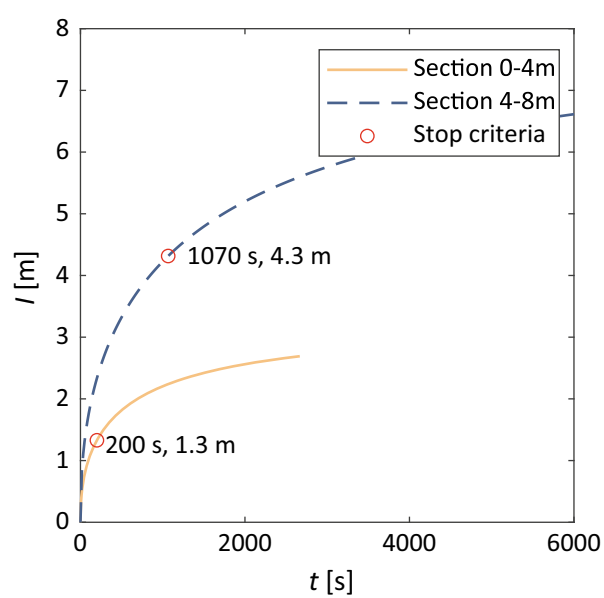

Fig. 9 Grout spread vs grouting time, and the stop criteria for the $0-4 \mathrm{~m}$ section and $4-8 \mathrm{~m}$ section

Table 5 Maximum grout spread and corresponding characteristic grouting time

\begin{tabular}{lllllll}
\hline Section & $\Delta P_{\mathrm{g}}(\mathrm{MPa})$ & $\tau_{0}(\mathrm{~Pa})$ & $b_{\mathrm{b}}(\mathrm{m})$ & $I_{\max }(\mathrm{m})$ & $\mu_{\mathrm{g}}(\mathrm{Pa} \bullet \mathrm{s})$ & $t_{0}(\mathrm{~s})$ \\
\hline $0-4 \mathrm{~m}$ & 0.2 & 6 & 0.0002 & 3.3 & 0.02 & 667 \\
$4-8 \mathrm{~m}$ & 0.5 & & & 8.3 & & 1667
\end{tabular}


( $\sim 18 \mathrm{~min}$ ) for a corresponding grout spread of $4.3 \mathrm{~m}$.

A check for jacking is necessary in order to verify the chosen stop criteria. In the calculation, the maximum fracture of each section is assumed to be located in the middle of the section. $\boldsymbol{\delta}_{\text {acc }}$ at the rock surface is chosen to be $0.2 \mathrm{~mm}$ in this design example. This is the same value as suggested by Statens Vattenfallsverk (1968). The check is performed according to Eqs. (19) to (24). Results of the check are shown in Table 6 and Fig. 10. No intersection is found between the pressure limiting curves and the grouting pressure line for either section, indicating that the grouting pressures fulfill the requirements for hydraulic jacking. It should be noted that in the calculation example, fracture dilation is not taken into account when calculating the grout spread. In reality, the fracture dilation can lead to a longer grout spread (Rafi and Stille 2021). This effect can be significant for the grout spread in fine fractures.

Since the stop criteria pass the check for jacking, the initial grout hole layout in Fig. 8 is verified. If the check would not have been passed, a modified grout hole layout is needed followed by another round of iteration, including determining new stop criteria and performing a new check for jacking. The iteration stops when the check for jacking is passed. At this point, the grout hole layout, together with the corresponding grouting pressures and stop criteria, constitutes the design of the grouting work.

\subsection{Summary}

A summary of the preliminary design for the rock mass domain of interest is presented in Table 7. It should be noted that the design of the grouting work is not unique for a given grout curtain design. Compared to the design shown in Table 7, a denser layout of the grout holes with shorter grouting time or lower grouting pressure can also obtain the same thickness of the grout curtain. This alternative can be beneficial

Table 6 Parameters to be used to check for hydraulic jacking

\begin{tabular}{llllll}
\hline$h(\mathrm{~m})$ & $k_{2}^{\prime}$ & $\Delta P_{\mathrm{g}}(\mathrm{MPa})$ & $P_{\mathrm{n}}$ & $P_{\mathrm{w}}(\mathrm{MPa})$ & $\delta_{\text {acc }}(\mathrm{mm})$ \\
\hline 2 & 1 & 0.2 & 1.28 & 0.02 & 0.2 \\
6 & & 0.5 & 1.07 & 0.06 & \\
\hline
\end{tabular}

if drilling and grouting more holes is more efficient in cost or time, compared to grouting longer time in fewer holes.

\section{Concluding Remarks}

This paper presents a theory-based design methodology for grout curtains. The methodology consists of a framework divided into three phases: preliminary design, grouting execution, and dam safety management. In the preliminary design, the grout curtain is designed as a structural component of the dam, where the design of the grout curtain and the design of the grouting work is distinguished. The main novelty is that the design of the grout curtain is based on a set of requirements which enables the geometry of the curtain to be determined based on the geological and hydrogeological conditions. In these requirements, the risk of erosion of fracture infilling material is explicitly accounted for together with the required reduction of the hydraulic conductivity of the rock mass, and an optimization of the total uplift force. The grouting work is thereafter designed using state-of-the-art theories of rock grouting for estimating grout spread over time and determining the grouting pressure with respect to hydraulic jacking. Stop criteria for grouting based on the grouting time are used. Using these theories enables the grouting work to be adapted to fulfill the desired geometry of the curtain. By implementing this methodology, the layout of the grout holes is no longer dependent on "rules of thumb", and the engineers can create a design more adapted to the prevailing geological and hydrogeological conditions of the rock mass. Applying the principles of the observational method during the grouting execution also enables the design to be modified by implementing predefined measures if the initial design is found to be unsuitable.

However, when applying the suggested methodology, the practicing engineer should be aware of the limitations that exist in the suggested design methodology as discussed in Sect. 2.5. The methodology can only be used for the design of grout curtains under new dams where the hydraulic gradient in the rock mass is low. In addition, the methodology is limited to fractured rock masses where the grout spread occurs radially in the discrete fractures. Furthermore, the methodology is only applicable for grout with 
(a)

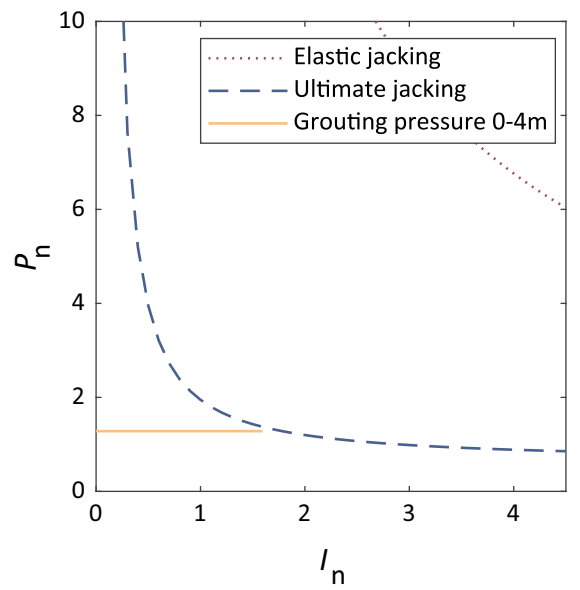

(b)

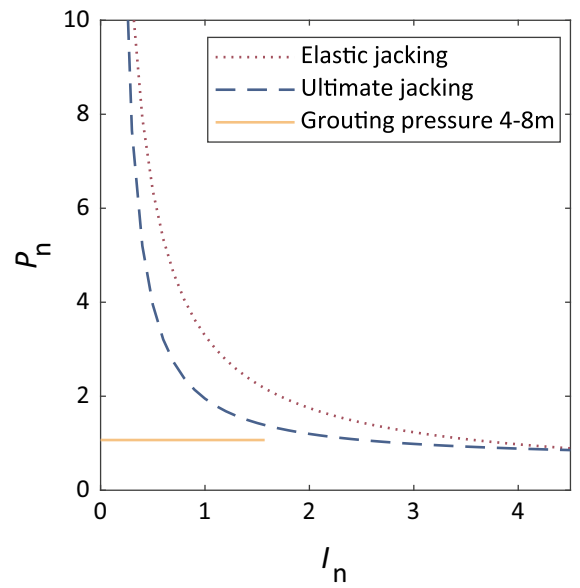

Fig. 10 Check for hydraulic jacking. a: Sect. 0-4 m; b: Sect. 4-8 m

Table 7 Summary of the preliminary design

\begin{tabular}{|c|c|c|c|c|c|}
\hline \multicolumn{2}{|c|}{ Design of the grout curtain } & \multicolumn{4}{|c|}{ Design of the grouting work } \\
\hline Thickness (m) & Depth $(\mathrm{m})$ & Grout and w:c ratio & Sections & $P_{\mathrm{g}}(\mathrm{MPa})$ & Grouting time (min) \\
\hline \multirow[t]{5}{*}{3} & 20 & INJ30 & $0-4 \mathrm{~m}$ & 0.2 & $\sim 4$ \\
\hline & & w:c ratio 1.0 by volume & $4-8 \mathrm{~m}$ & 0.6 & $\sim 18$ \\
\hline & & & $8-12 \mathrm{~m}$ & 0.6 & $\sim 18$ \\
\hline & & & $12-16 \mathrm{~m}$ & 0.6 & $\sim 18$ \\
\hline & & & $16-20 \mathrm{~m}$ & 0.7 & $\sim 18$ \\
\hline
\end{tabular}

Bingham properties, such as cementitious grout, and needs to be performed under temperature conditions which prevent freezing and enable hardening of the grout.

Although much research has been done on grouting, several parameters in the suggested design methodology are also associated with uncertainties. For example, the water velocities or critical gradients that cause erosion of the fracture infilling material to occur is a subject containing significant uncertainties, and more knowledge is needed. Empirical thresholds for sediment incipient motion, e.g. the Hjulström diagram (Hjulström 1935) and the Shields diagram (Shields 1936) may also be used for rough initial estimations. However, it should be kept in mind that these criteria were derived based on flume experiments and do not reflect the hydraulic conditions in a rock fracture. The uncertainties when applying these types of criteria are therefore large, and further research on the erosion of fracture infilling materials is needed. Grout spread is also a subject with significant uncertainties which are mainly related to the complex fracture pattern that a rock mass possesses. As mentioned previously, the simplified grout spread model will result in a spread that to some extent differs from the calculated spread. This modelling error, whose magnitude is not fully known, is worth further investigation. Due to the uncertainties associated with the design, validation of the method is therefore required by follow-up tests in the field as discussed in Sect. 2.3.

In addition, even though existing theories on grout spread have been successfully applied to grouting designs for different tunnel and dam projects, for example the Gotvand dam project (Rafi et al. 2012) and the THX dam project (Rafi 2014), a complete verification of these theories in the field has not yet been performed. Based on these limitations, among others, it is clear that there is room for further 
improvements in the different parts of the design methodology, and that a need for further research within these areas is desirable.

Despite the limitations of the methodology, and the uncertainties associated with some of the parameters in the design, it is our strong belief that the suggested design methodology provides a better control over the grouting design and also improves the ability to estimate time and costs associated with the construction of grout curtains. By ensuring that the critical gradient for any ungrouted fracture infilling materials that may exists in the grout curtain is not exceeded, we believe that it is possible to obtain a curtain with improved durability which will reduce the need for any future remedial grouting.

Acknowledgements The research presented in this paper was supported by the Swedish Hydropower Centre (SVC) (Grant No. VKU14130). SVC was established by the Swedish Energy Agency, Elforsk and Svenska Kraftnät together with Luleå University, KTH Royal Institute of Technology, Chalmers University of Technology and Uppsala University. http://www. svc.nu.

Authors' Contributions Not applicable.

Funding Open access funding provided by Royal Institute of Technology. The research presented in this paper was supported by the Swedish Hydropower Centre (SVC) (Grant No. VKU14130).

\section{Declarations}

Conflicts of interest Not applicable.

Ethics Approval Not applicable.

Consent to Participate Not applicable.

Consent for Publication Not applicable.

Availability of Data and Material Not applicable.

Code Availability Not applicable.

Open Access This article is licensed under a Creative Commons Attribution 4.0 International License, which permits use, sharing, adaptation, distribution and reproduction in any medium or format, as long as you give appropriate credit to the original author(s) and the source, provide a link to the Creative Commons licence, and indicate if changes were made. The images or other third party material in this article are included in the article's Creative Commons licence, unless indicated otherwise in a credit line to the material. If material is not included in the article's Creative Commons licence and your intended use is not permitted by statutory regulation or exceeds the permitted use, you will need to obtain permission directly from the copyright holder. To view a copy of this licence, visit http://creativecommons.org/licenses/by/4.0/.

\section{References}

Axelsson M (2009) Prevention of Erosion of Fresh Grout in Hard Rock. Doctoral thesis, Chalmers University of Technology

Barton N (1973) A review of the shear strength of filled discontinuities in rock. Paper presented at the Bergmekanikkdag, Oslo

Bonin G, Rombough V, Carter T, Jefferies M (2012) Towards Better Injection Control and Verification of Rock Grouting. Paper presented at the International Conference of Grouting and Deep Mixing, New Orleans

Brantberger M, Stille H, Eriksson M (2000) Controlling grout spreading in tunnel grouting-analyses and developments of the GIN-method Tunnelling and Underground Space Technology Vol. 15:343-352 doi:https://doi.org/10.1016/ S0886-7798(01)00003-7

Canadian Dam Association (CDA) (2007) Geotechnical considerations for dam safety. Tech Bull. Canadian Dam Association, Toronto

Carter T, Dershowitz W, Shuttle D, Jefferies M (2012) Improved Methods of Design for Grouting Fractured Rock. In: Paper presented at the international conference of grouting and deep mixing, New Orleans

Casagrande A (1961) Control of Seepage through Foundations and Abutments of Dams Géotechnique 11:161-182. https://doi.org/10.1680/geot.1961.11.3.161

Chai J, Cui W (2012) Optimum thickness of curtain grouting on dam foundation with minimum seepage pressure resultant Structural and Multidisciplinary Optimization. 45:303-308 Doi: https://doi.org/10.1007/s00158-0110699-7

Draganović A, Stille H (2011) Filtration and penetrability of cement-based grout: study performed with a short slot. Tunn Undergr Space Technol 26:548-559. https://doi.org/ 10.1016/j.tust.2011.02.007

Draganović A, Stille H (2014) Filtration of cement-based grouts measured using a long slot. Tunn Undergr Space Technol 43:101-112. https://doi.org/10.1016/j.tust.2014.04.010

Eklund D, Stille H (2008) Penetrability due to filtration tendency of cement-based grouts. Tunn Undergr Space Technol 23:389-398. https://doi.org/10.1016/j.tust.2007. 06.011

El Tani M (2012) Grouting rock fractures with cement grout. Rock Mech Rock Eng 54 (4):547-561. Doi: https://doi.org/ $10.1007 / \mathrm{s} 00603-012-0235-0$

El Tani M, Stille H (2017) Grout spread and injection period of silica solution and cement mix. Rock Fractures Rock Mech Rock Eng 50(9):2365-2380. Doi: https://doi.org/10.1007/ s00603-017-1237-8

El Tani M, Lopez-Molina J (2019) Running limit and refusal. Rock Fractures Grout Rock Mech Rock Eng 53:2201-2214. Doi: https://doi.org/10.1007/s00603-01902024-y 
Eriksson M, Stille H (2003) A method for measuring and evaluating the penetrability of grouts. In: Paper presented at the third international conference on grouting and ground treatment, New Orleans

Ewert FK, Hungsberg U (2018) Rock grouting at dam sites. Springer, Cham. https://doi.org/10.1007/978-3-31964036-5

Federal Energy Regulatory Commission (FERC) (2016) Engineering guidelines for the evaluation of hydropower projects: 3 revised chapter 3-gravity dams. Federal Energy Regulatory Commission, Washington

Funehag J, Fransson $\AA$ (2006) Sealing narrow fractures with a Newtonian fluid: model prediction for grouting verified by field study. Tunnell Underground Space Technol 21:492-498. Doi:https://doi.org/10.1016/j.tust.2005.08. 010

Funehag J, Thörn J (2018) Radial penetration of cementitious grout-Laboratory verification of grout spread in a fracture model. Tunnell Underground Space Technol 72:228-232. Doi: https://doi.org/10.1016/j.tust.2017.11.020

Gothäll R, Stille H (2009) Fracture dilation during grouting. Tunnell Underground Space Technol 24:126-135. Doi: https://doi.org/10.1016/j.tust.2008.05.004

Gustafson G, Stille H (1996) Prediction of groutability from grout properties and hydrogeological data. Tunnell Undergr Space Technol 11:325-332. Doi: https://doi.org/ 10.1016/0886-7798(96)00027-2

Gustafson G, Stille H (2005) Stop criteria for cement grouting Felsbau : Zeitschrift für Geomechanik und Ingenieurgeologie im Bauwesen und Bergbau 25:62-68

Gustafson G (2012) Hydrogeology for Rock Engineers. BeFo Rock Eng Res Found Stockholm

Håkansson U (1993) Rheology of fresh cement-based grouts. In: Doctoral thesis, KTH-Royal Institute of Technology

Hernqvist L, Einarsson V, Höglund A (2014) Does one fracture dominate the borehole transmissivity. In: Paper presented at the Swedish rock mechanics meeting, Stockholm

Hjulström F (1935) Studies of the morphological activity of rivers as illustrated by the river Fyris. In: Doctoral thesis, Uppsala University

Houlsby AC (1990) Construction and design of cement grouting. John Wiley and Sons, New York

International Commission on Large Dams (ICOLD) (1993) Bulletin 88: rock foundation for dams. International Commission on Large Dams, Paris

International Commission on Large Dams (ICOLD) (2017) Bulletin 164: internal erosion of existing dams, levees and dikes, and their foundations. International Commission on Large Dams, Paris

International Organization for Standardization (ISO) (2012a) ISO 22282-1:2012: Geotechnical investigation and testing — geohydraulic testing — part 1: general rules. International Organization for Standardization, Switzerland

International Organization for Standardization (ISO) (2012b) ISO 22282-2:2012: Geotechnical investigation and testing-geohydraulic testing-part 2: Water permeability tests in a borehole using open systems. International Organization for Standardization, Switzerland

International Organization for Standardization (ISO) (2012c) ISO 22282-3:2012: Geotechnical investigation and testing-geohydraulic testing - part 3: Water pressure tests in rock. International Organization for Standardization, Switzerland

Littlejohn GS (1982) Design of cement based grouts. Paper presented at the Grouting in Geotechnical Engineering, New Orleans

Lombardi G, Deere D (1993) Grouting design and dontrol using the gin. Principle Int Water Power Dam Construct 45:15-22

Nilsen B, Palmström A(2001) Stability and water leakage of hard rock subsea tunnels. In: Conference on modern tunneling science and technology, Kyoto. pp 497-502

Palmström A, Stille H (2014) Rock engineering, 2nd edn. ICE Publishing, London

Rafi JY, Stille H, Bagheri M (2012) Applying real time grouting control method in sedimentary rock. In: Paper presented at the the 4th international conference on grouting and deep mixing, New Orleans

Rafi JY (2014) Study of pumping pressure and stop criteria in grouting of rock fractures. In:Doctoral thesis, KTH-Royal Institute of Technology

Rafi JY, Stille H (2015a) Applicability of using gin method, by considering theoretical approach of grouting design. Geotech Geol Eng 33:1431-1448. Doi: https://doi.org/10.1007/ s10706-015-9910-8

Rafi JY, Stille H (2015b) Basic mechanism of elastic jacking and impact of fracture aperture change on grout spread, transmissivity and penetrability. Tunnell Underground Space Technol 49:174-187. Doi: https://doi.org/10.1016/j. tust.2015.04.002

Rafi JY, Stille H (2021) A method for determining grouting pressure and stop criteria to control grout spread distance and fracture dilation. Tunnell Underground Space Technol 112. Doi: https://doi.org/10.1016/j.tust.2021.103885

Ruggeri G (2004) Uplift pressures under concrete dams: final report. ICOLD European Club

Seed HB, Duncan JM (1987) The failure of Tetom dam. Eng Geol 24:173-205

Shields A (1936) Application of similarity principles and turbulence research to bed-load movement. Hydrodynamics Laboratory, California Institute of Technology, Pasadena. Publ. No. 167 (English translation)

Spross J, Johansson F, Uotinen LKT, Rafi JY (2016) Using observational method to manage safety aspects of remedial grouting of concrete dam foundations. Geotechn Geol Eng 34:1613-1630. Doi: https://doi.org/10.1007/s10706-0160069-8

Vattenfallsverk S (1968) Anvisningar för utförande av cementinjektering i berg. Statens Vattenfallsverk, Stockholm

Stille B, Stille H, Gustafson G, Kobayashi S (2009) Experience with the real time grouting control method. Geomech Tunnell 2. Doi: https://doi.org/10.1002/geot.200900036

Stille H, Gustafson G, Hässler L (2012) Application of new theories and technology for grouting of dams and foundations. Rock Geotech Geol Eng 30:603-624. Doi: https:// doi.org/10.1007/s10706-012-9512-7

Stille H (2015) Rock Grouting - Theories and Applications. BeFo-Rock Engineering Research Foundation, Stockholm

Swedenergy (2017) Kraftföretagens riktlinjer för dammsäkerhet (RIDAS) Avsnitt $\quad 7.3 \quad$ Betongdammar 
Tillämpningsvägledning (Swedish Hydropower Companies' Guidelines for dam safety). Swedenergy AB, Stockholm

Tsuji M, Holmberg M, Still B, Rafi JY, Stille H (2012) Optimization of the grouting procedure with RTGC method. Data from a trial grouting at city line project in Stockholm, SKB R-12-16 Svensk Kärnbränslehantering AB (SKB), Stockholm

United States Bureau of Reclamation (USBR) (1976) Design of Gravity Dams-Design Manual for Concrete Gravity Dams. Denver

Weaver KD, Bruce DA (2007) Dam Foundation Grouting, Revised and Expanded Edition. American Society of Civil Engineers (ASCE), Reston

Wilson D, Dreese TL (2003) Quantitatively Engineered Grout Curtains. In: Paper presented at the third international conference on grouting and ground treatment, New Orleans

Winberg A, Andersson P, Byegård J, Poteri A, Cvetkovic V, Dershowitz W, Doe T, et al. (2003) Final report of the TRUE Block Scale project-4. Synthesis of flow, transport and retention in the block scale. Swedish Nuclear Fuel and Waste Management Co, Stockholm

Zhang S, Johansson F (2021) On the required thickness of the grout curtain under dams. In: Paper presented at the ICOLD symposium on sustainable development of dams and river basins, New Delhi

Zimmerman RW, Bodvarsson GS (1996) hydraulic conductivity of rock fractures transport. Porous Media 23:1-30. Doi: https://doi.org/10.1007/BF00145263

Zou L, Jing L, Cvetkovic V (2015) Roughness decomposition and nonlinear fluid flow in a single rock fracture. Int J Rock Mech Min Sci 75:102-118. Doi: https://doi.org/10.1016/j. ijrmms.2015.01.016

Zou L, Håkansson U, Cvetkovic V (2018) Two-phase cement grout propagation in homogeneous water-saturated rock fractures. Int J Rock Mech Min Sci 106:243-249. Doi: https://doi.org/10.1016/j.ijrmms.2018.04.017

Zou L, Håkansson U, Cvetkovic V (2020) Analysis of Bingham fluid radial flow in smooth fractures. J Rock Mech Geotech Eng 12:1112-1118. Doi: https://doi.org/10.1016/j.jrmge. 2019.12.021

Publisher's Note Springer Nature remains neutral with regard to jurisdictional claims in published maps and institutional affiliations. 